\title{
Conservation for all, by all: making conservation effective and equitable
}

\author{
Helen Anthem and Kame Westerman
}

Conservation is ultimately a social process, and gender-the socially constructed roles and attributes associated with males and females-is a fundamental concept that influences use of natural resources, priorities for conservation, and ability to engage in decision-making about those resources. Women and men have different knowledge, experiences and perceptions, and are affected by environmental changes and conservation in different ways (McElwee et al., 2021). To conserve biodiversity, mitigate and adapt to climate change, and improve human well-being, it is critical to understand and respond to gender considerations.

Gender influences power and relations, and the rights and values that society places on different people. For example, despite women's use of and knowledge about natural resources, they often bear higher costs, and men tend to participate in and benefit more from conservation interventions. In India, for example, the presence of tigers in a landscape governed for conservation, combined with patriarchy and the pressures of dowry, deepened the vulnerability of women and girls to risk and violence (Doubleday \& Adams, 2020).

This issue of Oryx examines gender and conservation. Although gender has long been an issue of concern in the development sector, the conservation sector has been slower to act (James et al., 2021; Westerman, 2021) despite a growing body of evidence that the meaningful participation of women in resource governance leads to improved compliance, transparency, accountability and conflict resolution, greater equity and, ultimately, more effective conservation (Argawal, 2010; Leisher et al., 2017).

To some extent at least, the significance of gender is reflected in international environmental agreements (Westerman, 2021), and many conservation organizations have or are developing policies and accompanying guidance (James et al., 2021). Yet for many, gender concerns are seen as an add on (Westerman, 2021) or beyond their goals (Goldman et al., 2021). Despite some supportive policies and a growing body of good practices, significant challenges in implementation of gender-equitable conservation remain (Westerman, 2021).

Addressing gender inadequately, or even appearing blind to its importance, has been a long-standing issue in

Helen Anthem Fauna \& Flora International, The David Attenborough Building, Pembroke Street, Cambridge, CB2 3QZ, UK

E-mail helen.anthem@fauna-flora.org

KAME Westerman (iD orcid.org/0000-0003-3625-3619) Conservation International, Arlington, USA conservation. Many conservation projects that do purport to address gender focus solely on women. Goldman et al. (2021) refer to a commonly observed practice, in which women participate in conservation through handicraft initiatives or through a handful of female representatives on decision-making bodies. Although there is a need to focus on women because of their historical and ongoing exclusion, promoting women's participation alone is not enough, especially if the focus is not on their substantial influence or is on women's projects separate to the main conservation intervention. Alone, such approaches have limited impact on gendered power dynamics that perpetuate inequality and ultimately undermine conservation sustainability.

As in the natural sciences, gender bias towards men remains in social science research, including that around wildlife and natural resources (Corbera et al., 2021; Kahler \& Rinkus, 2021). A study of the production of knowledge on ecosystem services and poverty alleviation found that $70 \%$ of authors were male and 80\% studied in North America or Europe; biases that both shape and limit the focus and depth of research (Corbera et al., 2021). In contrast, a review of literature considering gender and conservation found that $70 \%$ of articles had female lead authors (James et al., 2021), perhaps reflecting the subject biases of male and female researchers or the common yet mistaken perception that gender is the domain of women. Less than $1 \%$ of academic research into wildlife crime even mentions the gender of respondents (Kahler \& Rinkus, 2021).

Gender bias in conservation is deep-rooted. Colonial powers introduced the exclusionary practices that continue today (Goldman et al., 2021). Big game hunting was a common pastime for colonists; a symbol of manliness epitomizing the separation of male and female domains. As male hunters turned conservationists, they made and enforced conservation practice, laws and policies to suit their interests (Flintan, 2003).

During the 1980s there was an increasing emphasis on community-based conservation, advocating participation by and benefits to local communities, but community-based conservation does not necessarily benefit all community members equitably, or at all. Argawal (2010) refers to participatory exclusions in which women and other marginalized groups are excluded from supposedly participatory institutions and processes. Conservation interventions frequently homogenize and romanticize communities; by ignoring differences within them, we bolster existing inequalities (Goldman et al., 2021). Although sacred forests 
have been hailed as models for community-based conservation, this ignores the fact that women are largely excluded from their management (Mokashi \& Diemont, 2021).

Greater recognition of the links between, and attempts to integrate, human rights and conservation (Springer et al., 2011) have contributed to an increasing focus on gender, but it cannot be assumed that this makes conservation interventions automatically gender-responsive. Using the term human rights denies '... the specific and particular problem of gender. It would be a way of pretending that it was not women who have, for centuries, been excluded. . For centuries, the world divided human beings into two groups and then proceeded to exclude and oppress one group. It is only fair that the solution to the problem should acknowledge that' (Adichie, 2014, p. 41).

Gender norms may limit the participation of women in conservation but they are neither static nor universal (Goldman et al., 2021). Culture, which shapes gender norms, is sometimes given as a reason for not addressing gender issues within conservation, yet culture is constantly changing and adapting to new ideas and social evolution.

Gender is complex and nuances are important (Kahler \& Rinkus, 2021), and it is necessary to recognize that both feminine and masculine identities and behaviours are diverse (Colfer, 2020). We need to look beyond the dualism of men and women and to examine how gender intersects with other factors such as marital status, age and ethnicity (Lau, 2020).

Although there are some key differences between the contexts in which the conservation and development sectors operate (Westerman, 2021), we can learn much from the development sector. This includes exploring and implementing more innovative or transformative approaches, such as addressing patriarchal systems, harmful masculinities and the gender norms that perpetuate gender-based discrimination, exploitation and violence (James et al., 2021). If conservation interventions do not consider and address gender differences they 'may be doomed to perpetuate them' (Larson et al., undated). In arguing for socially just conservation, Martin (2017) demonstrated that equity mediates conservation effectiveness through improved legitimacy and collective action. In the developing discourse on social justice and decolonizing conservation it is vital that the diversity of communities is considered, and that women's voices, amongst others, do not get excluded.

Responding to gender inequalities within conservation should not be an optional extra (James et al., 2021). The breadth of the articles in this issue, reflecting on the role of women and gender in wildlife crime, payments for ecosystem services, sacred forests, and conservation research and practice, demonstrates that gender is relevant to all that we do. These articles all point to the need for greater attention to gender and the need for further research. More meaningful discussion and consideration of gender issues within conservation research and practice will lead to more effective and equitable outcomes, advancing conservation for all, by all.

\section{References}

Adichie, C.N. (2014) We Should All Be Feminists. Fourth Estate, London, UK.

Argawal, B. (2010) Gender and Green Governance. The Political Economy of Women's Presence Within and Beyond Community Forestry. Oxford University Press, Oxford, UK.

Colfer, C. (2020) Masculinities in Forests: Representations of Diversity. Routledge, Abingdon, UK.

Corbera, E., Maestre-Andres, S., Calvet-Mir, L., Brockington, D., Howe, C. \& Adams, W.M. (2021) Biases in the production of knowledge on ecosystem services and poverty alleviation. Oryx, 55, 868-877.

Doubleday, K.F. \& AdAms, P.C. (2020) Women's risk and well-being at the intersection of dowry, patriarchy, and conservation: the gendering of human-wildlife conflict. Environment and Planning E: Nature and Space, 3, 976-998.

Flintan, F. (2003) 'Engendering' Eden: Women, Gender and ICDPs: Lessons Learnt and Ways Forward. Summary Document. Wildlife and Development Series No.16, International Institute for Environment and Development, London, UK. pubs.iied.org/ 9231IIED [accessed 23 September 2021].

Goldman, M.J., Jagadeesh, S.N., Meng'oru Ngimojino, T. \& GowDA, L.M. (2021) Women's stories and knowledge of wildlife and conservation practice in northern Tanzania and South India. Oryx, 55, 818-826.

James, R., Gibbs, B., Whitford, L., Leisher, C., Konia, R. \& Butt, N. (2021) Conservation and natural resource management: where are all the women? Oryx, 55, 860-867.

KAHLER, J.S. \& Rinkus, M.A. (2021) Women and wildlife crime: hidden offenders, protectors and victims. Oryx, 55, 835-843.

LAU, J.D. (2020) Three lessons for gender equity in biodiversity conservation. Conservation Biology, 34, 1589-1591.

Larson, A.M., Dokken, T. \& Duchelle, A.E. (undated) Can Safeguards Guarantee Gender Equity? Lessons from Research on Women in Early REDD+ Implementation. CIFOR, Bogor, Indonesia. cifor.org/publications/pdf_files/SafeguardBrief/5191brief.pdf [accessed 23 September 2021].

Leisher, C., Booker, F., Agarwal, B., Day, M., Matthews, E., Prosnitz, D. et al. (2018) A preliminary theory of change detailing how women's participation can improve the management of local forests and fisheries. Preprint publication. SocArXiv, doi.org/10. 31235/osf.io/rgakw.

Martin, A. (2017) Just Conservation: Biodiversity, Wellbeing and Sustainability. Routledge, Abingdon, UK.

McElwee, P., Lê, H.T.V., NGhiêm, T.P., Vư, H.D. \& Trần, N.H. (2021) Gender and payments for environmental services: impacts of participation, benefit-sharing and conservation activities in Viet Nam. Oryx, 55, 844-852.

Mokashi, S. \& Diemont, S.A.W. (2021) Access denied: understanding the relationship between women and sacred forests in western India. Oryx, 55, 827-834.

Springer, J., Campese, J. \& Painter, M. (2011) Conservation and Human Rights: Key Issues and Contexts. Scoping Paper for the Conservation Initiative on Human Rights, WWF, Washington, DC, USA. thecihr.org/s/Conservation_and_Human_Rights_Key_ Issues_and_Contexts.pdf [accessed 1 Octobe 2021].

Westerman, K. (2021) Unpacking the perceived benefits and costs of integrating gender into conservation projects: voices of conservation field practitioners. Oryx, 55, 853-859. 